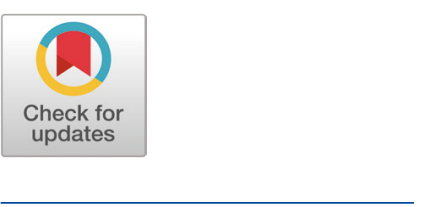

Received: Jul 2, 2020

Revised: Aug 7, 2020

Accepted: Aug 11, 2020

*Corresponding author

Chul-Ju Yang

Department of Animal Science \&

Technology, Sunchon National University,

Suncheon 57922, Korea.

Tel: +82-61-750-3235

E-mail: yangcj@scnu.ac.kr

Copyright $\odot 2020$ Korean Society of Animal Sciences and Technology.

This is an Open Access article distributed under the terms of the Creative Commons Attribution

Non-Commercial License (http:// creativecommons.org/licenses/bync/4.0/) which permits unrestricted non-commercial use, distribution, and reproduction in any medium, provided the original work is properly cited.

ORCID

Eun Ju Yang

https://orcid.org/0000-0002-9120-7079

Ye Seul Seo

https://orcid.org/0000-0001-8491-5117

Muhammad Ammar Dilawar

https://orcid.org/0000-0003-3012-1447

Hong Seok Mun

https://orcid.org/0000-0003-0322-6462

Hyeoung Seog Park

https://orcid.org/0000-0001-8314-0321

Chul Ju Yang

https://orcid.org/0000-0003-3510-3096

Competing interests

No potential conflict of interest relevant to this article was reported.

\section{Physico-chemical attributes, sensory evaluation and oxidative stability of leg meat from broilers supplemented with plant extracts}

\author{
Eun Ju Yang ${ }^{1}$, Ye Seul Seo ${ }^{1}$, Muhammad Ammar Dilawar ${ }^{2}$, Hong Seok Mun², \\ Hyeoung Seog Park ${ }^{3}$ and Chul Ju Yang ${ }^{2 *}$ \\ ${ }^{1}$ Food Research Center, Jeonnam Bioindustry Foundation, Naju 58275, Korea \\ ${ }^{2}$ Department of Animal Science \& Technology, Sunchon National University, Suncheon 57922, Korea \\ ${ }^{3} E F C$, Gwangyang 57714, Korea
}

\section{Abstract}

This feeding trial was conducted to investigate the effects of Mentha arvensis (MA) and Geranium thunbergii (GT) in drinking water on physicochemical attributes, sensory qualities, proximate analysis and oxidative stability of broiler leg meat. One hundred and twenty broiler chicks were assigned to 1 of 4 dietary treatments for 5 weeks. The dietary treatments were 1) control, 2) T1 (0.1\% $1 \mathrm{MA}: 1 \mathrm{GT}), 3) \mathrm{T} 2$ (0.1\% $1 \mathrm{MA}: 4 \mathrm{GT}), 4)$ T3 (0.1\% 4 MA: $1 \mathrm{GT})$. The water holding capacity and cooking loss were improved $(p<0.05)$ in T2 and T3. The flavor, texture and acceptability of leg meat by consumers were significantly increased in T2 relative to the control $(p<0.05)$. The crude protein content was increased in T3 while the crude fat decreased in T2 $(p<0.05)$. Moreover, broilers supplemented with plant extracts had the lowest leg meat TBARS (thiobarbituric acid reactive substances) values after 2 weeks of storage as compared with the control. Total phenolic contents and 1-1-diphenyl 2 picrylhydrazyl (DPPH) activity were also better in the T2 group $(p<0.05)$ compared with the control, whereas 2,2-Azinobis-3 ethytlbenzothiazoline-6-sulfonic acid $\left(\mathrm{ABTS}^{+}\right)$remained unaffected. Overall, these results demonstrate that broiler drinking water with the inclusion of plant extract combination can be used to enhance the oxidative stability, shelf life and quality characteristics of broiler leg meat without compromising the growth performance.

Keywords: Broiler leg meat, Oxidative stability, Plant extracts, Shelf life

\section{INTRODUCTION}

Poultry meat quality is determined by not only physical and chemical properties but also by consumer preference. As the consumption of meat is increasing, consumer interest in healthy food is also increasing worldwide, as is the demand for high-quality products with safety and better shelf life [1]. Meat quality traits can be classified into three groups i) appearance quality traits including drip loss, color and texture of meat; ii) eating quality trait including tenderness, juiciness, succulence and flavor of cooked meat [2]; and iii) reliance quality traits including safety, nutritive value, animal welfare, market price, 
Funding sources

This research was supported by the MOTIE (Ministry of Trade, Industry \& Energy), Korea Institute for Advancement of Technology (KIAT) by the Encouragement Program for the Industries of Economic Cooperation Region (R0005793).

Acknowledgements

Not applicable.

Availability of data and material Upon reasonable request, the datasets of this study can be available from corresponding author.

\section{Authors' contributions}

Conceptualization: Yang EJ, Seo YS, Yang CJ. Data curation: Yang EJ, Seo YS, Dilawar MA, Mun HS.

Formal analysis: Yang EJ, Seo YS, Dilawar MA, Mun HS, Park HS.

Methodology: Yang EJ, Dilawar MA, Mun HS, Park HS.

Software: Yang EJ, Seo YS, Mun HS.

Validation: Mun HS, Park HS, Yang CJ.

Investigation: Yang EJ, Seo YS, Dilawar MA, Mun HS, Park HS.

Writing - original draft: Dilawar MA, Yang CJ. Writing - review \& editing: Yang EJ, Seo YS, Dilawar MA, Mun HS, Park HS, Yang CJ.

Ethics approval and consent to participate The experimental protocols and management and care of broilers were approved and reviewed by the Institutional Animal Care and Use Committee (IACUC), Sunchon National University (SCNU IACUC 2019-05). ethics, product packaging, brand and origin of meat products [3].

The oxidative process has a negative impact on the growth and performance of animals and deteriorates meat quality. Unfortunately, chicken meat is highly susceptible to oxidation reactions because of a high degree of unsaturation in muscles, which results in loss of flavor, appearance, and nutritive value [4]. During recent years, people have had many concerns regarding the safety of meat and its effect on their health, ageing and oxidative processes. Therefore, increased attention is being given to the rearing of birds without the use of synthetic antioxidants, antibiotics or chemicals [5]. Plant extracts possess a variety of physiologically active substances that exhibit antioxidant activity. Different kinds of plant extracts have been shown to increase animal feed intake, endogenous digestive enzyme secretions and boosting the immune system. As a result, providing birds with feed amended with such extracts leads to increased poultry productivity and meat quality characteristics [6].

Mentha arvensis (MA) is a species of herbal plant belongs to the Lamiaceae family and the extracts of this plant has been used in folk medicine for several therapeutic purposes. This plant yields 40\%-50\% menthol, which is a primary phenolic compound having antioxidant, antibacterial and antiseptic properties. The contents of antioxidant compounds in this plant are as follows: Vit $\mathrm{C}$, $12.8 \pm 0.08 \mathrm{mg} \%$; Vit E, $0.0294 \pm 0.0015 \mathrm{mg} \%$; carotenoid, $4.48 \pm 0.06 \mathrm{mg} \%$; total content of phenolics, $70.0 \pm 0.13 \mathrm{mg} \%$ [7]. The other plant of interest is Geranium thunbergii (GT), which belongs to the Geraniaceae family. This plant has been reported to exhibit anti-oxidative, anti-inflammatory, anti-mutagenic, antibacterial, anti-hypertensive and antifungal activities [8]. The leaves of this plant contain a crystalline tannin called geraniin ( $10 \%$ of total dry weight), which is used in the treatment of diarrhoea. The total phenolics of this plant are $104 \pm 2.4 \mathrm{mg} \mathrm{GAE} / \mathrm{g}$ and the Gallic acid content is $2,313 \pm 10.8 \mathrm{mg} / 100 \mathrm{~g}$ dried sample, which indicates that it has good antioxidant activity [9].

A way of enhancing the efficacy of plant extracts may be the water supplementation, which ensures uniform mixing into water, uniform intake by birds and to avoid wastage [10]. Skomorucha and Sosnówka-czajka [11] also reported that the response of broilers to the water supplementation with certain herbs was positive in terms of growth performance, physiological response to stress and welfare. Therefore, this study was conducted to meet consumer preference for safe, hygienic, less prone to oxidative processes and antibiotic-free poultry meat. The present study investigated if the plant extracts in drinking water would improve carcass color coordination, physio-chemical attributes, sensory evaluation and oxidative stability of broiler leg meat.

\section{MATERIALS AND METHODS}

The experimental protocols and management and care of broilers were approved and reviewed by the Institutional Animal Care and Use Committee (IACUC), Sunchon National University, Korea (SCNU IACUC 2019-05).

\section{Manufacture of plant extracts}

Two plants, MA and GT, were purchased from Bonghwa, South Korea. The leaves were thoroughly washed, dried and ground, after which the extract of both plants were prepared according to the method described by Dilawar et al. [10] . Briefly, MA and GT extracts were prepared separately by mixing $100 \mathrm{~g}$ of leaves with $5 \mathrm{~L}$ distilled water and kept for $2 \mathrm{~h}$ in the dark at room temperature, with occasional shaking. This method was repeated for the extraction of $2 \mathrm{~kg}$ dried leaves of both plants, after which the samples were filtered with the help of Whatman No. 1 filter paper. The combination treatments were prepared in the broiler house before adding to the drinking water. 


\section{Birds and housing}

A total of 120, day-old male "Ross" broiler chickens were reared and housed according to the guidelines set on the Aviagen [12]. A feeder at the front side and a nipple drinker at the back were placed in the cage for free access to feed and water (with dietary treatment inclusion) throughout the whole experiment.

\section{Dietary treatments}

The ingredients, vitamin and mineral content and calculated chemical composition of the basal diets are presented in Table 1. Commercially available poultry feed (Nonghyup feed, Gyeongsangnam-do, Korea) were fed to the birds as basal diet. A preliminary experiment was conducted by Dilawar et al. [10] to identify the percentage and ratio of two plant extracts on broiler performance and feed conversion ratio (data not shown). The broiler leg meat samples from the treatments which performed best were further evaluated in this experiment. The treatments used in this study were 1) control, 2) T1 (0.1\% 1 MA:1 GT), 3) T2 (0.1\% 1 MA:4 GT), 4) T3 (0.1\% 4 MA: 1 GT). Birds were weighed individually and randomly divided into four treatment groups in five replicates with six birds each.

Table 1. Feed ingredients and chemical composition of diets

\begin{tabular}{|c|c|c|}
\hline Ingredient (\%, as-fed basis) & Starter & Finisher \\
\hline Corn & 50.00 & 56.00 \\
\hline Soybean meal & 37.00 & 28.84 \\
\hline Corn gluten meal & 0.50 & 1.00 \\
\hline Wheat $10 \%$ & 6.00 & 7.00 \\
\hline Limestone-small & 2.03 & 1.92 \\
\hline Salt-Proc & 0.25 & 0.25 \\
\hline DCP $18 \%$ & 0.40 & 0.46 \\
\hline L-Lys sulfate $70 \%$ & 0.30 & 0.18 \\
\hline Minemix $^{1)}$ & 0.20 & 0.20 \\
\hline Vitamix $^{2)}$ & 0.05 & 0.05 \\
\hline L-Threonine 98\% & - & 0.01 \\
\hline MHA-Liquid & 0.26 & 0.29 \\
\hline Sunphase5000FTU & 0.01 & 0.01 \\
\hline Soybean oil & 3.00 & 3.80 \\
\hline Total & 100.00 & 100.00 \\
\hline \multicolumn{3}{|l|}{ Calculated composition (\%DM) } \\
\hline $\mathrm{ME}(\mathrm{kcal} / \mathrm{kg})$ & $3,090.97$ & $3,207.91$ \\
\hline Crude protein (\%) & 22.04 & 19.00 \\
\hline Crude fat (\%) & 5.35 & 6.23 \\
\hline Crude ash (\%) & 5.71 & 5.26 \\
\hline Crude fibre (\%) & 2.59 & 2.39 \\
\hline $\mathrm{Ca}(\%)$ & 1.09 & 1.04 \\
\hline Phosphorus (\%) & 0.45 & 0.43 \\
\hline Lysine (\%) & 1.34 & 1.07 \\
\hline Methionine (\%) & 0.57 & 0.55 \\
\hline \multicolumn{3}{|c|}{$\begin{array}{l}\text { 1).2) Vitamin-mineral mixture provided the following nutrients per kilogram of diet: vitamin A 12,061.00 IU (starter) and 12,122.00 } \\
\text { IU (finisher); vitamin } \mathrm{D}_{3} 3,000.00 \mathrm{IU} \text {; vitamin E } 28.06 \mathrm{ppm} \text { (starter) and } 29.35 \mathrm{ppm} \text { (finisher); vitamin K 2.10 ppm (starter) and } \\
2.11 \mathrm{ppm} \text { (finisher); choline chloride 1,329.10 ppm (starter) and 1,146.20 ppm (finisher); copper } 73.02 \mathrm{ppm} \text { (starter) and } 72.07 \\
\text { ppm (finisher); manganese } 77.92 \mathrm{ppm} \text { (starter) and } 75.80 \mathrm{ppm} \text { (finisher); zinc } 73.75 \mathrm{ppm} \text { (starter) and } 71.57 \mathrm{ppm} \text { (finisher); } \\
\text { iodine } 0.94 \mathrm{ppm} \text {; selenium } 0.30 \mathrm{ppm} \text {; iron } 148.63 \mathrm{ppm} \text { (starter) and 4,141.21 ppm (finisher). }\end{array}$} \\
\hline
\end{tabular}




\section{Sampling procedure and analysis}

At 36 days of age, two birds were randomly selected from every replicate cage (10 birds/ treatment) and slaughtered by cutting the jugular veins. The whole leg portion (drumstick and thigh) was excised from the carcass, after which the meat from the leg was separated by removing the bones, skin and connective tissues. Leg meat samples from each bird (3 replicates) were refrigerated at $4{ }^{\circ} \mathrm{C}$ for TBARS (thiobarbituric acid reactive substances), $\mathrm{pH}$, sensory evaluation, water holding capacity (WHC) and cooking loss determination and $-20^{\circ} \mathrm{C}$ for other analysis.

The color coordination was determined with the help of a Chroma meter (CR-410, Konika Minolta Sensing, Tokyo, Japan) and presented in CIE unit (The International Commission of Illumination, 1978) of $a^{*}, L^{*}$, and $b^{*}$. The chroma meter was calibrated using a white ceramic tile (as standard) throughout the study.

The $\mathrm{pH}$ of leg meat sample was measured with a $\mathrm{pH}$ meter (Seven Excellence, Metler-Toledo AG, Greifensee, Switzerland) by homogenizing $1 \mathrm{~g}$ of minced broiler meat and $9 \mathrm{~mL}$ of water for 1.5 minutes at 20,000 rpm with a homogenizer (UltraTurrax T-25, Staufen, Germany).

After $24 \mathrm{~h}$ postmortem, leg meat samples $(1.5 \mathrm{~cm}$ thick and $80 \mathrm{~g}$ weight) were cut and placed in polyethene bags and were then placed in a water bath at $75^{\circ} \mathrm{C}$ for 30 minutes. The bags were then cooled for one hour at room temperature. The samples were subsequently cooked using a Combi Oven (MCS-6, Henny Penny, Eaton, Oh, USA). Cooking loss was determined for each sample (three replicates) by calculating the percentage of the cooked sample (W2) and the weight of the uncooked sample (W1). The percentage of cooking loss was calculated according to the following formula: Cooking loss $(\%)=[\mathrm{W} 1-\mathrm{W} 2 / \mathrm{W} 1] \times 100$.

The WHC was determined in three replicates per sample using the procedure described by Bostami et al. [13]. In a short, a $300 \mathrm{mg}$ leg meat sample was compressed in a filter-press device for $2 \mathrm{~min}$. After the filter press and compression, meat samples were individually weighed. The amount of expelled water was calculated by evaluating the initial to the final weight of compressed and filter pressed samples. A lower water expulsion indicated the higher WHC and vice versa. The WHC was calculated and expressed as a percentage.

Sensory evaluation was conducted by 10 trained judges. Chicken leg meat samples were boiled in water before evaluation until the internal temperature raised to $70^{\circ} \mathrm{C}$. The temperature was checked by placing a thermometer in the geometric center of the meat sample. The scale of 1 to 7 was used for the evaluation of meat sample as follows: color (1: very light/pale, 7: reddish black color), flavor intensity (1: very poor, 7: excellent), tenderness (1: extremely hard, 7: very soft/tender), palatability (1: low, 7: high) juiciness (1: very dry, 7: succulent) and overall acceptability (1: extremely unaccepted, 7: highly acceptable).

The proximate composition of chicken leg meat samples was analyzed according to the AOAC guidelines and procedures [14].

The TBARS values of the leg meat samples were measured at 0,1 , and 2 weeks after storage according to the procedure explained by Ahmed et al. [15] . About $4 \mathrm{~g}$ leg meat was added to a 10 $\mathrm{mL}$ solution consisting of $20 \%$ trichloracetic acid and homogenized in a homogenizer (UltraTurrax $\mathrm{T}-25$, Staufen, Germany) at maximum speed of 25,000 rpm for $1.5 \mathrm{~min}$. The mixture was then filtered through a micro no. 60 filter paper (Hyundai Seoul, Korea). Two $\mathrm{mL}$ of the filtered solution and $2 \mathrm{~mL}$ of 2-thiobarbituric acid were placed in a shaking heating water bath for $30 \mathrm{~min}$ at $80^{\circ} \mathrm{C}$. The absorbance was determined at $530 \mathrm{~nm}$ after cooling with the help of a VIS Spectrophotometer (S22 Libra, Biochrom Limited, Cambridge, UK). The TBARS value was presented as milligrams of MDA (malondialdehyde) per $100 \mathrm{~g}$ of meat.

The total phenolics were measured using Folin-Ciocalteu reagent. Briefly, $15 \mathrm{~mL}$ of distilled water was added to $5 \mathrm{~g}$ of chicken leg meat sample, vortexed for 1 minute and centrifuged for 10 
minutes at 3,000×g. To measure the total phenolic compounds, $100 \mu \mathrm{L}$ of $50 \%$ Folin Ciocalteau's reagent (Sigma-Aldrich, St. Louis, Mo, USA) and $2 \mathrm{~mL}$ of $2 \% \mathrm{Na}_{2} \mathrm{CO}_{3}$ solution and were added to each $15 \mu \mathrm{L}$ sample (three replicates) and incubated for 15 mins at $45^{\circ} \mathrm{C}$. The absorbance was subsequently measured at $710 \mathrm{~nm}$ using a spectrophotometer and quantification was conducted based on a curve obtained with Gallic acid.

DPPH (1-1-diphenyl 2 picrylhydrazyl) radical scavenging ability was determined according to the method explained by Jang et al. [16]. Briefly, $200 \mu \mathrm{L}$ of each prepared sample (three replicates) by the same method as the total phenol compound. The samples were amended with $1 \mathrm{~mL}$ of methanolic $0.2 \mathrm{mM}$ DPPH solution (Wako Pure Chemical, Osaka, Japan) and $800 \mu \mathrm{L}$ of water and, mixed and allowed to react for $30 \mathrm{~min}$, after which the absorbance was calculated at $517 \mathrm{~nm}$ using a spectrophotometer. A tube containing $1 \mathrm{~mL}$ of DPPH $(0.2 \mathrm{mM})$ and $1 \mathrm{~mL}$ of distilled water was used as a control and the DPPH was calculated by the following equation:

$\mathrm{DPPH}$ radical scavenging ability $(\%)=$

[1 - (Absorbance of the sample / Absorbance of a control) $] \times 100$

ABTS $^{+}$(2,2-azinobis-3 ethytlbenzothiazoline-6-sulfonic acid) was mixed in water to a $7 \mathrm{mM}$ concentration and ABTS radical cations were generated by the reaction of $2.45 \mathrm{mM}$ potassium persulphate and ABTS stock solution. A total of $10 \mu \mathrm{L}$ of the sample prepared in the same manner as the total phenolic compound content was mixed with $1 \mathrm{~mL}$ diluted ABTS prepared solution and reacted at room temperature for 6 minutes. Finally, the absorbance was determined at $734 \mathrm{~nm}$ using a spectrophotometer. The ABTS radical scavenging ability of each sample (three replicates) was then calculated by the following equation:

ABTS scavenging ability $(\%)=[1-($ Absorbance of sample $/$ Absorbance of the control $)] \times 100$

\section{Statistical analysis}

All experimental data were examined using the SPSS program (Statistics Package for Social Science, version 15.1, SPSS, Chicago, IL, USA) to determine if variables differed between groups. Each cage was used as the experimental unit for growth production parameters, whereas an individual chick served as the experimental unit for proximate composition, $\mathrm{ABTS}^{+}, \mathrm{DPPH}$ and total phenolic contents. The statistical equation used to test the effects of treatment was:

$$
Y_{i j}=\mu+\alpha_{i}+e_{i j}
$$

where $Y_{\mathrm{ij}}=$ the response variable, $\mu$ = the general mean, $\alpha_{\mathrm{i}}=$ the effect of dietary treatments, and $\mathrm{e}_{\mathrm{ij}}=$ the error. The means were determined and expressed with the SEM. All parameters were compared between groups by one-way ANOVA and subsequent Duncan's multiple range tests. A $p<0.05$ was considered significant.

\section{RESULTS}

Table 2 shows the $L^{*}, a^{*}$, and $b^{*}$ color values of poultry leg meat. The $L^{*}$ and $a^{*}$ values differed significantly between groups. Specifically, the $\mathrm{L}^{*}$ values of T1 and T2 was higher as compared with the control and T3 $(p<0.05)$. Additionally, the redness value of the control was significantly $(p<$ 0.05 ) higher than T1 and T2. In the case of yellowness, there was no significant difference between treatments and the control. The $\mathrm{pH}$ of leg meat samples did not differ significantly between dietary 
Table 2. Effects of two plant extracts on color values, pH, cooking loss and WHC of broiler meat

\begin{tabular}{|c|c|c|c|c|c|c|}
\hline \multirow{2}{*}{ Item } & \multicolumn{4}{|c|}{ Dietary treatments $(n=10)$} & \multirow{2}{*}{ SEM } & \multirow{2}{*}{$p$-value } \\
\hline & Control & $\mathrm{T1}$ & T2 & T3 & & \\
\hline CIE L* & $52.70^{\mathrm{bc}}$ & $55.64^{b}$ & $55.05^{\mathrm{ab}}$ & $51.24^{\mathrm{c}}$ & 0.48 & 0.036 \\
\hline $\mathrm{CIE} a^{*}$ & $9.13^{\mathrm{a}}$ & $5.82^{\mathrm{bc}}$ & $5.35^{c}$ & $7.82^{\mathrm{ab}}$ & 0.12 & 0.021 \\
\hline $\mathrm{CIE} b^{*}$ & 15.75 & 16.13 & 17.45 & 16.09 & 0.26 & 0.648 \\
\hline $\mathrm{pH}$ & 6.88 & 6.74 & 6.67 & 6.68 & 0.10 & 0.139 \\
\hline Cooking loss (\%) & $26.87^{\mathrm{a}}$ & $26.83^{\mathrm{a}}$ & $22.43^{\mathrm{b}}$ & $22.72^{\mathrm{b}}$ & 1.31 & 0.01 \\
\hline WHC (\%) & $37.48^{b}$ & $39.37^{\mathrm{ab}}$ & $41.97^{\mathrm{a}}$ & $42.09^{\mathrm{a}}$ & 0.73 & 0.013 \\
\hline
\end{tabular}

$\mathrm{n}$, number of birds.

${ }^{a-c}$ Within the same row, mean values with different superscripts are significantly different $(p<0.05)$.

WHC, water holding capacity.

treatments (Table 2).

Cooking loss was significantly reduced in T2 and T3 $(p<0.05)$, with the greatest cooking loss seen in the control (Table 2$)$. The WHC was increased significantly $(p<0.05)$ in T2 and T3 compared with the control.

There were no differences found in the color and taste of the leg meat samples (Table 3). However, the flavor, texture, juiciness and overall acceptability of meat supplemented with T2 were preferred $(p<0.05)$ over the control by the panellists.

There was no significant difference in the moisture content of the leg meat sample among groups (Table 4). However, the crude protein (CP) contents were significantly higher $(p<0.05)$ in the broiler leg meat fed diet T3, while the crude ash content was higher $(p<0.05)$ in T2 relative to the other treatments.

On an average and after 2 weeks of storage, leg meat TBARS value was decreased significantly

Table 3. Effects of two plant extracts on sensory properties of broiler meat

\begin{tabular}{|c|c|c|c|c|c|c|}
\hline \multirow{2}{*}{ Items } & \multicolumn{4}{|c|}{ Dietary treatments $(n=10)$} & \multirow{2}{*}{ SEM } & \multirow{2}{*}{$p$-value } \\
\hline & Control & T1 & T2 & T3 & & \\
\hline Color & 4.25 & 5.00 & 5.50 & 4.75 & 0.20 & 0.524 \\
\hline Flavor & $3.75^{\mathrm{b}}$ & $4.00^{\mathrm{b}}$ & $5.00^{\mathrm{a}}$ & $3.75^{\mathrm{b}}$ & 0.15 & 0.011 \\
\hline Taste & 4.25 & 5.50 & 5.75 & 5.00 & 0.20 & 0.224 \\
\hline Texture & $4.00^{b}$ & $4.75^{\mathrm{ab}}$ & $5.25^{a}$ & $4.25^{\mathrm{ab}}$ & 0.18 & 0.028 \\
\hline Juiciness & $3.75^{\mathrm{b}}$ & $4.25^{\mathrm{ab}}$ & $5.50^{a}$ & $5.25^{\mathrm{a}}$ & 0.16 & 0.024 \\
\hline Overall acceptability & $4.00^{\mathrm{b}}$ & $5.00^{\mathrm{ab}}$ & $5.75^{a}$ & $4.50^{\mathrm{ab}}$ & 0.22 & 0.031 \\
\hline
\end{tabular}

n, number of birds.

a,b Within the same row, mean values with different superscripts are significantly different $(p<0.05)$.

Table 4. Effects of two plant extracts on proximate composition of broiler meat

\begin{tabular}{|c|c|c|c|c|c|c|}
\hline \multirow{2}{*}{ Items } & \multicolumn{4}{|c|}{ Dietary treatments $(n=10)$} & \multirow{2}{*}{ SEM } & \multirow{2}{*}{$p$-value } \\
\hline & Control & T1 & T2 & T3 & & \\
\hline Moisture & 74.60 & 74.48 & 74.50 & 74.24 & 2.60 & 0.418 \\
\hline Crude protein & $18.29^{c}$ & $18.69^{b c}$ & $18.57^{\text {bc }}$ & $19.19^{\mathrm{a}}$ & 0.50 & $<0.001$ \\
\hline Crude fat & $2.43^{\mathrm{ab}}$ & $2.47^{\mathrm{ab}}$ & $2.10^{b}$ & $2.78^{\mathrm{a}}$ & 0.02 & 0.001 \\
\hline Crude ash & $1.00^{\mathrm{bc}}$ & $0.96^{c}$ & $1.14^{\mathrm{a}}$ & $1.01^{b}$ & 0.01 & 0.001 \\
\hline
\end{tabular}

$\mathrm{n}$, number of birds.

${ }^{a-c}$ Within the same row, mean values with different superscripts are significantly different $(p<0.05)$. 
$(p<0.05)$ in the plant extracts supplemented groups (Table 5). However, no significant differences were found at 0 and 1 weeks of storage.

The phenolic contents of the leg meat varied from 71.07 to $78.03 \mathrm{mg}$ GAE $/ \mathrm{kg}$ of meat (Table 6). The meat from chickens fed T2 showed significantly greater total phenols and DPPH scavenging activity compared with the control group $(p<0.05)$. In the case of $\mathrm{ABTS}^{+}$scavenging, there were no differences $(p>0.05)$ among groups. Clearly, the $31.5 \%$ increase in the DPPH and $5 \%$ increase in the $\mathrm{ABTS}^{+}$scavenging effect of 2 compared to the control was because of the presence of higher total phenolic contents.

\section{DISCUSSION}

The color value of meat, $\mathrm{L}^{*}$ is linked with visual color observation, the $\mathrm{a}^{*}$ value is related to oxidation state, intramuscular fat and pigment content and the $b^{*}$ value is associated with redox state and intramuscular fat content [13]. In this study, the $\mathrm{L}^{*}$ color value ranged from 51.24 to 58.50 , the $\mathrm{a}^{*}$ color value from 5.82 to 9.13 and the $\mathrm{b}^{*}$ color value from 15.75 to 17.45 . This variation in meat color was in accordance with the results of previous studies that showed the addition of phytogenics such as black pepper, red pepper and garlic in poultry diets influenced meat color [17].

Different authors suggested different cut off values of $\mathrm{L}^{*}$ to determine meat quality. For poultry meat, Petracci et al. [18] suggested $L^{*}<50$ was dark, $50 \leq L^{*} \leq 56$ was normal and $L^{*}>56$ was pale. In this experiment, the $\mathrm{L}^{*}$ values of the control, $\mathrm{T} 1, \mathrm{~T} 2$, and $\mathrm{T} 3$ were $52.70,55.64,55.05$, and 51.24 , respectively, which indicates that leg meat $L^{*}$ value lies in the normal cut off range. Redness value decreased in response to the addition of extract from MA and GT to the diets of birds as compared with the control. According to Amorim et al. [19], a decreased a* value is a result of a higher percentage of fat deposition and intramuscular fat and a proportional decrease in the blood vessels; therefore, a low meat $\mathrm{a}^{*}$ value results in brighter meat (higher $\mathrm{L}^{*}$ value), which was also found in this experiment.

The $\mathrm{pH}$ value varied from 6.67 to 6.88 in the meat samples. In this trial, the $\mathrm{pH}$ values of leg

Table 5. Effects of two plant extracts on TBARS value of broiler meat

\begin{tabular}{|c|c|c|c|c|c|c|}
\hline \multirow{2}{*}{ Storage period } & \multicolumn{4}{|c|}{ Dietary treatments $(n=10)$} & \multirow{2}{*}{ SEM } & \multirow{2}{*}{$p$-value } \\
\hline & Control & T1 & T2) & T3 & & \\
\hline 0 -wk & 0.30 & 0.29 & 0.30 & 0.29 & 0.03 & 0.09 \\
\hline $1-w k$ & 0.35 & 0.30 & 0.24 & 0.30 & 0.04 & 0.30 \\
\hline 2-wk & $0.48^{\mathrm{a}}$ & $0.27^{\mathrm{bc}}$ & $0.30^{\mathrm{bc}}$ & $0.22^{c}$ & 0.05 & 0.001 \\
\hline Average & $0.34^{\mathrm{a}}$ & $0.26^{\mathrm{bc}}$ & $0.24^{c}$ & $0.25^{c}$ & 0.02 & 0.02 \\
\hline
\end{tabular}

$\mathrm{n}$, number of birds.

a-c Within the same row, mean values with different superscripts are significantly different $(p<0.05)$.

TBARS, thiobarbituric acid reactive substances.

Table 6. Effects of two plant extracts on total phenolic contents $(\mu \mathrm{g} / \mathrm{g})$, DPPH $(\%)$ and ABTS $(\%)$ radical scavenging activity of broiler meat

\begin{tabular}{|c|c|c|c|c|c|c|}
\hline \multirow{2}{*}{ Item } & \multicolumn{4}{|c|}{ Dietary treatments $(n=10)$} & \multirow{2}{*}{ SEM } & \multirow{2}{*}{$p$-value } \\
\hline & Control & T1 & T2 & T3 & & \\
\hline Total phenols (ppm) & $71.07^{b}$ & $77.33^{\mathrm{ab}}$ & $78.03^{\mathrm{a}}$ & $73.75^{\mathrm{ab}}$ & 2.45 & 0.041 \\
\hline DPPH radical scavenging activity (\%) & $33.37^{\mathrm{b}}$ & $34.80^{\mathrm{b}}$ & $43.90^{\mathrm{a}}$ & $35.59^{b}$ & 1.15 & 0.031 \\
\hline ABTS radical scavenging activity (\%) & 55.47 & 53.73 & 58.33 & 53.86 & 1.50 & 0.135 \\
\hline
\end{tabular}

$\mathrm{n}$, number of birds.

a,b Within the same row, mean values with different superscripts are significantly different $(p<0.05)$.

DPPH, 1-1-diphenyl 2 picrylhydrazyl; ABTS, 2,2-azinobis-3 ethytlbenzothiazoline-6-sulfonic acid. 
meat samples were same with the findings of a previous trial performed by Džinić et al. [17], in which meat samples with a $\mathrm{pH}$ more than 5.8 was considered as normal meat for quality purpose. The lowest $\mathrm{pH}$ value (6.67) was observed in T2 and the lowest $\mathrm{a}^{*}$ color value was also found in $\mathrm{T} 2$, which is in line with the results of previous experiments that showed light color poultry meat samples had significantly lower $\mathrm{pH}$ [20]. A high $\mathrm{pH}$ and microbial count is usually an indicator of meat spoilage and it is of great significance that the $\mathrm{pH}$ of the meat reaches as low as possible for better shelf life. The highest $\mathrm{pH}$ was observed in the control (6.88) relative to supplemented groups, indicating reduced spoilage of meat because of supplementation with plant extracts. Supporting the results of the current study, different researchers also reported a decline in the $\mathrm{pH}$ of meat because of the addition of phytogenics such as pomegranate by-products and $2 \%$ garlic acid $[5,15]$.

The WHC is important for customers as it has a significant role in determining the final weight of the meat. In this study, supplementation of broilers with plant extracts increased the WHC and decreased the cooking loss $(p<0.05)$, suggesting increased retention of nutrients and better quality of meat. Cooking loss is very important to the meat industry as the main point of the profit is water retention. The relationship between $\mathrm{WHC}$, muscle $\mathrm{pH}$ and meat color is well established. Positive influences of plants extract on meat quality of chickens have been observed by many scientists using different supplements and similar to our findings, Džinić, et al. [17] reported the lowest cooking and drip-loss of meat after feeding animals hot red pepper.

According to the consumer's point of view, juiciness, flavor and tenderness are the most critical factors for eating satisfaction [1]. Supplementation of broilers with MA and GT increased the flavor, texture, juiciness and acceptability of the poultry meat. Specifically, the overall acceptability of $\mathrm{T} 1, \mathrm{~T} 2$, and $\mathrm{T} 3$ were $5,5.75$, and 4.50 , respectively, on a scale of 7 , while that of the control was only 4. Some authors reported that the supplementation of natural anti-oxidants to the lamb, pigs and poultry did not have adverse or beneficial effects on sensory characteristics of meat [21]. Furthermore, Džnić et al. [17] reported a characteristic pungent smell and taste being transferred to the meat due to the supplementation of poultry feed with $2 \%$ garlic. This characteristic of flavor can be beneficial or non-beneficial depending on consumer preference. Conversely, an overall improvement in meat quality attributes without any atypical smell was observed in this study in response to the addition of plant extracts.

In general, the proximate composition and nutritive value of meat will depend on the diet, age, genetics, sexual maturity, management and environmental conditions of the source animal. In the present study, the non-significant moisture content is consistent with the findings of Gardzielewska et al. [22], who reported that dietary feed of broiler chickens supplemented with echinacea (Echinacea purpurea), ginger (Zingiber officinale) and garlic (Allium sativum) did not show any effect on the moisture content of meat. In our study, moisture content was lowest (74.24\%) and crude fat content was highest (2.78\%) in birds supplemented with T3. This might have been because of the inverse relationship between fat content and meat moisture, which is directly linked with meat juiciness [23]. The CP content of leg meat was higher in T3 (19.19\%) than the control (18.29\%), which was related to the high meat quality in birds supplemented with plant extract. In previous trials by Puvača et al. [5], there was a significant improvement in the protein content of poultry meat because of the dietary supplementation of garlic, red and black pepper. In short, supplementation of the feed with plant extracts showed beneficial effects on the proximate composition of chicken meat and had the ability to increase the nutritive value of meat. This may be due to the reason that muscles of animals are the main cause of deterioration of meat quality and oxidation of these muscles affect the nutritional and organoleptic properties [24]. The phenolics in MA and GT have the ability to stop these reactions and enhance the meat quality.

During the processing and storage of chicken meat, oxidative deterioration is responsible for 
rancid odor and flavor. It is understood that the free radicals produced during lipid oxidation can cause ageing of cells, cancer, cardiovascular diseases and neurodegenerative disorders [25]. The potential of the phenolics to act as antioxidant depends mainly on the redox effects of phenolic hydroxyl groups, which allows them to quench free radicals because of their high radical-absorbance or $\mathrm{H}^{\circ}$-donating ability [26]. Moreover, the shelf life of packed chicken meat is short because of rapid microbial growth and lipid oxidation. In the present study, supplementation of feed with different proportions of MA and GT significantly decreased the lipid oxidation, as represented by the decreased meat TBARS value. These values are consistent with the findings of Biswas et al. [27], showing the presence of natural antioxidants in MA. Furthermore, a 9.80\% increase in total phenolic contents in the supplemented group was observed because of high phenolic, flavonoid and tannin chemical contents present in the Geraniaceae and Lamiaceae family [28]. Phenolic compounds in both plants (MA and GT) have antioxidant activities and therefore have the ability to improve the meat quality and increase the shelf life of stored meat. Similar beneficial effects of both plants on the oxidative stability has been reported in broiler meat [10,29].

Free stable radical DPPH is commonly used to estimate the efficiency of plant extracts as oxidants. The results of our study indicated that the supplementation of dietary plant extracts improved the radical scavenging activity in leg meat. Similar to our findings, Jang et al. [16] reported that the free radical scavenging effect of chicken meat increased because of supplementation with medicinal herbal extract mix). In the present trial, better scavenging activity in the chicken meat supplemented with MA and GT was because of the presence of polyphenols in natural antioxidants. In addition, a feeding trial conducted by Wong et al. [25], MA had the second-highest DPPH free radical capturing activity among 25 plants and the third-highest antioxidant index (10.9) among 43 plants [7].

It has been suggested by Nagendra Prasad et al. [30] that the polyphenolic content of plant extracts were closely related to the antioxidant capacity $\left(R^{2}=0.9773\right)$. In addition, the phenolic components in plant extracts react with hydroxyl radicals and lipid to form stable products that may increase scavenging ability [16]. Similar to our findings, Luna et al. [31] and Goñi et al. [32] reported that the addition of dietary phenolic sources led to significant anti-oxidation activities in chicken and lamb meat.

\section{CONCLUSION}

In conclusion, supplementation of plant extracts improved the nutritional value of broiler leg meat and a combination of MA and GT in T2 produced the most promising effects among all treatments. The combination of plant extracts in $\mathrm{T} 2$ improved the nutritive value and composition of broiler leg meat by increasing the mineral content (total ash) and decreasing the ether extract. In addition to the good WHC and minimum cooking loss in T2, the leg meat was highly acceptable by consumers because of its better juiciness, color, flavor and texture. The higher total phenolic contents, better DPPH and $\mathrm{ABTS}^{+}$radical scavenging ability and decreased meat TBARS value indicate that plant extracts combination in T2 is capable of improving oxidative stability, shelf life and quality of broiler leg meat without having a negative impact on growth performance.

\section{REFERENCES}

1. Saha A, Perumalla AVS, Lee Y, Meullenet JF, Owens CM. Tenderness, moistness, and flavor of pre- and postrigor marinated broiler breast fillets evaluated by consumer sensory panel. Poult Sci. 2009; 88:1250-6. https://doi.org/10.3382/ps.2008-00236

2. Ismail I, Joo ST. Poultry meat quality in relation to muscle growth and muscle fiber char- 
acteristics. Korean J Food Sci Anim Resour. 2017; 37:873-83. https://doi.org/10.5851/kosfa.2017.37.6.873

3. Troy DJ, Kerry JP. Consumer perception and the role of science in the meat industry. Meat Sci. 2010; 86:214-26. https://doi.org/10.1016/j.meatsci.2010.05.009

4. Estévez M. Oxidative damage to poultry: from farm to fork. Poult Sci. 2015;94:1368-78. https://doi.org/10.3382/ps/pev094

5. Puvača N, Kostadinović Lj, Popović S, Lević J, Ljubojević D, Tufarelli V, et al. Proximate composition, cholesterol concentration and lipid oxidation of meat from chickens fed dietary spice addition (Allium sativum, Piper nigrum, Capsicum annuum). Anim Prod Sci. 2015;56:1920-7. https://doi.org/10.1071/AN15115

6. Hygreeva D, Pandey MC, Radhakrishna K. Potential applications of plant based derivatives as fat replacers, antioxidants and antimicrobials in fresh and processed meat products. Meat Sci. 2014;98:47-57. https://doi.org/10.1016/j.meatsci.2014.04.006

7. Chanwitheesuk A, Teerawutgulrag A, Rakariyatham N. Screening of antioxidant activity and antioxidant compounds of some edible plants of Thailand. Food Chem. 2005;92:491-7.https:// doi.org/10.1016/j.foodchem.2004.07.035

8. Sung YY, Yoon T, Yang WK, Kim SJ, Kim HK. Anti-obesity effects of Geranium thunbergii extract via improvement of lipid metabolism in high-fat diet-induced obese mice. Mol Med Rep. 2011; 4:1107-13. https://doi.org/10.3892/mmr.2011.568

9. Kim M, Park J, Lim S. Antioxidant activity and cell toxicity of pressurised liquid extracts from 20 selected plant species in Jeju, Korea. Food Chem. 2010;122:546-52. https://doi.org/10.1016/ j.foodchem.2010.03.007

10. Dilawar MA, Saturno JFL, Mun HS, Kim DH, Jeong MG, Yang CJ. Influence of two plant extracts on broiler performance, oxidative stability of meat and odorous gas emissions from excreta. Ann Anim Sci. 2019;19:1099-113. https://doi.org/10.2478/aoas-2019-0046

11. Skomorucha I, Sosnówka-Czajka E. Effect of water supplementation with herbal extracts on broiler chicken welfare / Wpływ Dodatku Do Wody Ekstraktów Ziołowych Na Dobrostan Kurcząt Brojlerów. Ann Anim Sci. 2013;13:849-57. https://doi.org/10.2478/aoas-2013-0057

12. Aviagen. Ross broiler management handbook [Internet]. 2018 [cited 2020 Jul 20]. http:// en.aviagen.com/assets/Tech_Center/Ross_Broiler/Ross-BroilerHandbook2018-EN.pdf

13. Bostami ABMR, Mun HS, Yang CJ. Loin eye muscle physico-chemical attributes, sensory evaluation and proximate composition in Korean Hanwoo cattle subjected to slaughtering along with stunning with or without pithing. Meat Sci. 2018;145:220-9. https://doi. org/10.1016/j.meatsci.2018.06.032

14. AOAC [Association of Official Analytical Chemists] International. Official methods of analysis of AOAC International. 18th ed. Gaithersburg, MD: AOAC International; 2005.

15. Ahmed ST, Islam MM, Bostami ABMR, Mun HS, Kim YJ, Yang CJ. Meat composition, fatty acid profile and oxidative stability of meat from broilers supplemented with pomegranate $(\mathrm{Pu}-$ nica granatum L.) by-products. Food Chem. 2015;188:481-8. https://doi.org/10.1016/j.foodchem.2015.04.140

16. Jang A, Liu X, Shin M, Lee B, Lee S, Lee J, et al. Antioxidative potential of raw breast meat from broiler chicks fed a dietary medicinal herb extract mix. Poult Sci. 2008;87:2382-9. https:// doi.org/10.3382/ps.2007-00506

17. Džinić $\mathrm{N}$, Puvača N, Tasić T, Ikonić $\mathrm{P}$, Okanović Đ. How meat quality and sensory perception is influenced by feeding poultry plant extracts. World's Poult Sci J. 2015;71:673-82. https://doi. org/10.1017/S0043933915002378

18. Petracci M, Betti M, Bianchi M, Cavani C. Color variation and characterization of broiler 
breast meat during processing in Italy. Poult Sci. 2004;83:2086-92. https://doi.org/10.1093/ ps/83.12.2086

19. Amorim A, Rodrigues S, Pereira E, Teixeira A. Physicochemical composition and sensory quality evaluation of capon and rooster meat. Poult Sci. 2016;95:1211-9. https://doi.org/10.3382/ ps/pev448

20. Qiao M, Fletcher DL, Smith DP, Northcutt JK. The effect of broiler breast meat color on $\mathrm{pH}$, moisture, water-holding capacity, and emulsification capacity. Poult Sci. 2001;80:676-80. https://doi.org/10.1093/ps/80.5.676

21. Chaves AV, Stanford K, Gibson LL, McAllister TA, Benchaar C. Effects of carvacrol and cinnamaldehyde on intake, rumen fermentation, growth performance, and carcass characteristics of growing lambs. Anim Feed Sci Technol. 2008;145:396-408. https://doi.org/10.1016/j.anifeedsci.2007.04.016

22. Gardzielewska J, Pudyszak K, Majewska T, Jakubowska M, Pomianowski JF. Effect of plant-supplemented feeding on fresh and frozen storage quality of broiler chicken meat. Electron J Pol Agric Univ. 2003;6:\#12.

23. Ahmed ST, Mun HS, Islam MM, Ko SY, Yang CJ. Effects of dietary natural and fermented herb combination on growth performance, carcass traits and meat quality in grower-finisher pigs. Meat Sci. 2016;122:7-15. https://doi.org/10.1016/j.meatsci.2016.07.016

24. Insani EM, Eyherabide A, Grigioni G, Sancho AM, Pensel NA, Descalzo AM. Oxidative stability and its relationship with natural antioxidants during refrigerated retail display of beef produced in Argentina. Meat Sci. 2008;79:444-52.https://doi.org/10.1016/j.meatsci.2007.10.017

25. Wong SP, Leong LP, Koh JHW. Antioxidant activities of aqueous extracts of selected plants. Food Chem. 2006;99:775-83. https://doi.org/10.1016/j.foodchem.2005.07.058

26. Lampart-Szczapa E, Korczak J, Nogala-Kalucka M, Zawirska-Wojtasiak R. Antioxidant properties of lupin seed products. Food Chem. 2003;83:279-85. https://doi.org/10.1016/S03088146(03)00091-8

27. Biswas NN, Saha S, Ali MK. Antioxidant, antimicrobial, cytotoxic and analgesic activities of ethanolic extract of Mentha arvensis L. Asian Pac J Trop Biomed. 2014;4:792-7. https://doi. org/10.12980/APJTB.4.2014C1298

28. Yang YC, Li J, Zu YG, Fu YJ, Luo M, Wu N, et al. Optimisation of microwave-assisted enzymatic extraction of corilagin and geraniin from Geranium sibiricum Linne and evaluation of antioxidant activity. Food Chem. 2010;122:373-80. https://doi.org/10.1016/j.foodchem.2010.02.061

29. Khempaka S, Pudpila U, Molee W. Effect of dried peppermint (Mentha cordifolia) on growth performance, nutrient digestibility, carcass traits, antioxidant properties, and ammonia production in broilers.J Appl Poult Res. 2013;22:904-12. https://doi.org/10.3382/japr.2013-00813

30. Nagendra Prasad K, Yang B, Yang S, Chen Y, Zhao M, Ashraf M, et al. Identification of phenolic compounds and appraisal of antioxidant and antityrosinase activities from litchi (Litchi sinensis Sonn.) seeds. Food Chem. 2009;116:1-7. https://doi.org/10.1016/j.foodchem.2009.01.079

31. Luna A, Lábaque MC, Zygadlo JA, Marin RH. Effects of thymol and carvacrol feed supplementation on lipid oxidation in broiler meat. Poult Sci. 2010;89:366-70. https://doi. org/10.3382/ps.2009-00130

32. Goñi I, Brenes A, Centeno C, Viveros A, Saura-Calixto F, Rebolé A, et al. Effect of dietary grape pomace and vitamin $\mathrm{E}$ on growth performance, nutrient digestibility, and susceptibility to meat lipid oxidation in chickens. Poult Sci. 2007;86:508-16. https://doi.org/10.1093/ ps/86.3.508 